\section{Fast lege til fast lønn}

Da fastlegereformen ble innført i 2001, var bakgrunnen et langvarig ønske fra både myndigheter og leger om å styrke primærhelsetjenesten. Men det var uenigheter om virkemidlene. Helsemyndighetene ønsket at det offentlige skulle overta både ansvar og drift av allmennlegetjenesten, helst med fast ansatte leger. Legeforeningen på sin side ønsket å bevare allmennpraksis som et fritt yrke med refusjoner fra folketrygden. Men heller ikke blant legene var det enighet: Et økende antall primærleger, og da særlig blant de yngre, hadde i tiårene før fastlegereformen ønsket offentlig ansettelse på fast lønn (1). For med økt satsing på primærhelsetjenesten fra 1970-årene og fremover fulgte større behov for gode lokaler, godt utstyr og mer hjelpepersonell. Utgiftene til å etablere egen praksis økte, og flere og flere yngre vegret seg. Som en konsekvens steg antallet fastlønnsstillinger i kommunene. I 1990 ble toppen nådd. Da hadde nesten 40 \% av allmennlegene fastlønn (1). Med fastlegereformen kom privat næringsdrift til de grader som den foretrukne organisasjonsformen: Rett etter innføringen av ordningen i 2001 var $10,3 \%$ av praksisene fastlønnet. I 2015 var andelen mer enn halvert, til kun 4,3\% (2).

De siste årene har flere unge leger igjen offentlig tatt til orde for å revidere en ordning som tvinger nesten alle fastleger inn i privat næringsdrift (3-5). Argumentene er, som før, at store utgifter og høyt krav til inntjening skremmer yngre leger bort fra faget (4) samt at incentivsystemet fører til overforbruk av tjenester og skjeve prioriteringer i klinisk praksis (3). Og svaret fra Legeforeningens tillitsvalgte er som tidligere at «næringsdrift er den beste måten å sikre god kvalitet og kontinuitet i helsetjenesten» (6). Historien gjentar seg: Igjen synes det å være de unge mot de etablerte i synet på hvilken avlønningsform som er best for den offentlige allmennlegetjenesten.

Ordningen med stykkprisbasert betaling for å drive en offentlig tjeneste er en pussighet i norsk sammenheng. Få vil ivre for å innføre noe lignende for andre grupper offentlige tjenesteytere, som lærere, politifolk eller sykehusleger. Når ordningen likevel har bestått uten særlig protester, henger det sammen med at fastlegereformen har vært en suksess - med privat næringsdrift for de deltagende leger som en integrert del av denne. Av samme grunn er det svært vanskelig å evaluere stykkprisbetalingen løsrevet fra fastlegeordningen som sådan.

Og for dem som har forsøkt, har resultatene vært blandet. Selv om omfattende litteratur viser at økonomiske incentiver kan ha effekt på legers atferd (7), er det vanskeligere å vise dette i praksis. Et åpenbart problem med dagens stykkprissystem er for eksempel at fastlegene, som er portvoktere for sine pasienters tilgang til offentlige goder, samtidig har de samme pasientene som «kunder» i et «marked» blant andre fastleger. I hvilken grad det kan gi overforbruk av goder, for eksempel sykmeldinger, er dog vanskelig å påvise. Det er beregnet at ved en tenkt omlegging til fastlønn for alle fastleger i Norge, ville sykefraværet falle med 3-4\% (7). Tallene er beheftet med stor usikkerhet, og det tas heller ikke høyde for andre effekter av en slik tenkt omlegging.
Det andre hovedargumentet for økt bruk av fastlønn har vært at unge leger, og særlig kvinner, flykter fra allmennpraksis på grunn av høye krav til inntjening, få muligheter til faglig oppdatering uten inntektstap samt manglende sykepengerettigheter og permisjonsordninger i selvstendig næringsdrift som fastlege $(4,5)$. Alderssammensetningen av fastlegekorpset har dog i hovedsak vært lik de siste årene, med en liten økning av andelen fastleger under 40 år (2). Men om man ser på kjønnsfordelingen, trer et noe annet bilde frem. Andelen kvinner av alle leger under 70 år økte med $42 \%$ fra 2002 til 2014. I samme periode økte kvinneandelen av fastlegene bare med $33 \%$ (8) - det vil si en relativ nedgang $i$ andelen kvinnelige leger i fastlegepraksis.

Samtidig har det vært en klar holdningsendring i fastlegekorpset når det gjelder ønsket avtaleform. Andelen som ønsker privat næringsdrift, har falt fra 52\% i 2009 til 36\% i 2012 (9). Og det var de unge fastlegene i små kommuner som i størst grad ønsket fastlønnsordninger. Tendensen er enda tydeligere blant de helt unge: Under $20 \%$ av både turnusleger og studenter ønsker seg en betalingsordning som dagens stykkpris (10). Ikke overraskende var det i både denne og andre undersøkelser kvinnene som i minst grad ønsket seg dagens system for fastlegepraksis.

Dette siste er viktig. For det er kvinnene som er morgendagens leger: I februar 2017 er 66,3\% av medlemmene av Norsk medisinstudentforening kvinner (11). I en situasjon der rekrutteringen til fastlegepraksis er i fare og fastlegene flykter fra distriktene (12), trenger vi mer og bedre kunnskap om effektene av ulike betalingsordninger for fastleger, ikke minst i den sårbare etablerings- og spesialiseringsfasen. Fastlegeordningen kommer til å være det viktigste helsetilbudet til befolkningen også i fremtiden. Vi må lytte til ønskene til den neste generasjonen som skal bemanne og bekvinne ordningen. Gjør vi det, tyder mye på at fremtidens faste leger kommer til å ha fast lønn.

\footnotetext{
Litteratur

1. Sandvik H. Evaluering av fastlegereformen 2001-2005: sammenfatning og analyse av evalueringens delprosjekter. Oslo: Norges forskningsråd, 2006.

2. Fastlegestatistikk. Utviklingstrekk og endringer i fastlegeordningen. Helsedirektoratet. https://helsedirektoratet.no/statistikk-og-analyse/fastlegestatistikk\# fastlegestatistikk (14.2.2017)

3. Østby K. Fastlegens perverse incentiver. Aftenposten 31.1.2017.

4. Lie AD. Fastlønn for fastleger? Ja, takk. Aftenposten 2.2.2017.

5. Wennevold K. Arbeidsvilkår i allmennmedisin - modent for revisjon? Troms legeforening. Skalpellen. 18.2.2013. https://legeforeningen.no/lokal/troms/ Skalpellen/Arbeidsvilkar-i-allmennmedisin--modent-for-revisjon/ (14.2.2017).

6. Øren TO. Fastlønn for alle leger er ikke svaret. Aftenposten 9.2.2017

7. Markussen S, Røed K. The market for paid sick leave. IZA Discussion Paper 2016; nr. 9825

8. Abelsen B, Gaski M, Brandstorp H. Varighet av fastlegeavtaler. Tidsskr Nor Legeforen 2015; 135: 2045-9.

9. Holte JH, Abelsen B, Halvorsen PA et al. General practitioners' altered preferences for private practice vs. salaried positions: a consequence of proposed policy regulations? BMC Health Serv Res 2015; 15: 119

10. Abelsen B, Olsen JA. Does an activity based remuneration system attract young doctors to general practice? BMC Health Serv Res 2012; 12: 68.

11. Legestatistikk Legeforeningen. https://legeforeningen.no/Emner/Andre-emner/ Legestatistikk/ (14.2.2017)

12. Sollien K. Fastlegene flykter fra distriktene. Dagens Medisin 1.2.2016.
} 